\title{
Beyond Black and White: Biracial Attitudes in Contemporary U.S. Politics
}

\author{
LAUREN D. DAVENPORT Stanford University
}

\begin{abstract}
7 he 2000 U.S. census was the first in which respondents were permitted to self-identify with more than one race. A decade later, multiple-race identifiers have become one of the fastest-growing groups in the nation. Such broadening multiracial identification poses important political ramifications and raises questions about the future of minority group political solidarity. Yet we know little about the opinions of multiple-race identifiers and from where those opinions emerge. Bridging literatures in racial politics and political socialization, and drawing upon a multimethod approach, this article provides insight into the consequences of the U.S.'s increasingly blurred racial boundaries by examining the attitudes of Americans of White-Black parentage, a population whose identification was traditionally constrained by the one-drop rule. Findings show that on racial issues such as discrimination and affirmative action, biracials who identify as both White and Black generally hold views akin to Blacks. But on nonracial political issues including abortion and gender/marriage equality, biracials who identify as White-Black or as Black express more liberal views than their peers of monoracial parentage. Being biracial and labeling oneself a racial minority is thus associated with a more progressive outlook on matters that affect socially marginalized groups. Two explanations are examined for these findings: the transmission of political outlook from parents to children, and biracials' experiences straddling a long-standing racial divide.
\end{abstract}

\section{INTRODUCTION}

$\mathbf{I}$ n the 2000 U.S. census, in what has been called "the greatest change in the measurement of race in the history of the United States" (Farley 2002, 33 ), respondents were allowed, for the first time ever, to self-identify with more than one racial group. Today, multiple-race identifiers are one of the fastest-growing demographics (Pew 2015). The rise in this population, coupled with an increasing intermarriage rate and the election of President Obama, have catalyzed public discourse regarding the significance of multiracialism in 21 st century U.S. politics. ${ }^{1}$

The biracial children of White-Black unions in particular symbolize the intimate crossing of a strict racial periphery (Myrdal 1944; Reuter 1918). For nearly a century, these individuals typically identified as Black, keeping in line with the "one-drop rule." 2 But since

Lauren D. Davenport is Assistant Professor, Stanford University, Department of Political Science, 305 Encina Hall West, 616 Serra Street, Stanford, CA 94035-6044 (ldd@stanford.edu).

I thank Chris Achen, Nick Ahamed, Will Bullock, Gary Cox, Annie Franco, Paul Frymer, Chelsea Green, Martin Gilens, Justin Grimmer, Vincent Hutchings, Brianna Pang, Gary Segura, Paul Sniderman, and Aimee Trujillo. I am also grateful to the Higher Education Research Institute (HERI) and Cooperative Institutional Research Program (CIRP) at UCLA for providing Freshman Survey data access, as well as the Princeton Center for African American Studies and the Bobst Institute for Peace and Justice for financial support. The analysis dataset for this article is hosted by HERI and can be requested here: http://www.heri.ucla.edu/gainaccess.php. Analysis files are available at https://people.stanford.edu/ldd/research.

${ }^{1}$ In 2010,15 percent of new marriages were interracial or interethnic, up from just 6.7 percent in 1980. Among all married couples, the share of intermarriages was 8.4 percent, up from 3.2 percent 30 years prior (Wang 2012)

2 However, there have always been cleavages among Black Americans by skin tone and White heritage (Hochschild and Weaver 2007; Keith and Herring 1991) and from 1850 to 1920, census enumerators recorded individuals by their percentage Black ancestry (Nobles 2000).
2000, the number of Americans identifying as White and Black has more than tripled, currently making it the largest multiple-race subgroup (Bureau of the Census 2015).

The widespread adoption of this new racial label reflects a discontinuity from the past and a rupture to racial norms. Whereas racial identification was often treated as an ascribed trait devoid of choice in U.S. politics, it has become more of a conscious decision than an automatic label (Nagel 1995), and there is a growing percentage of the population for whom race is not a mutually exclusive concept (Lee 2008; Telles and Sue 2009; Williams 2006). The decision to identify oneself with multiple groups instead of more conventional, singular racial labels signals a break from tradition - and a declaration of racial affect that poses substantive political repercussions. Historically, Blacks of mixed-race have been integral in advancing the political agenda of the Black American community (Davis 2001; Du Bois 1903b; White 1948). In choosing to assert a multiple-race label, White-Black identifiers are consciously differentiating themselves from Black Americans - and this shift in identification has raised serious questions about minority group solidarity and Black political cohesiveness (Shelby 2005; Williams 2006).

Yet, what does it really mean, politically, to identify with multiple racial groups? Does a multiple-race label signify a weakening of minority identity and a desire to distance oneself politically from Blacks? Or is the embrace of multiple labels instead an affirmative identification that suggests a progressive approach to racial and social issues? Racial meanings have always been fundamental to the structuring of American politics, and disparities between Whites and Blacks have been an enduring element of race relations (Hutchings and Valentino 2004; Kinder and Sanders 1996). But what do people of White-Black parentage look like, 
sociodemographically, and where do they reside in the political divide?

At present, we lack the answer to these questions, though some work has started to examine the political implications of multiracialism. Notably, Masuoka (2011) proposes two competing hypotheses regarding the political consequences of mixed-race identity: first, that it is an expression of positive self-regard that is not associated with a particular political perspective, and second, that a multiracial identity is related to a particular outlook that does shape an individual's political perspective and attitudes. Moreover, in their study of the implications that multiracialism poses for the American racial order, Hochschild, Weaver, and Burch $(2012,8)$ argue that, "the race or ethnicity with which a person identifies or is identified is becoming less and less predictive of his or her views, behaviors, and, eventually, life chances."

But in putting forth such conjectures, these works have tended to neglect seminal social psychological theories including the marginal man hypothesis (Park 1928; 1931; Stonequist 1935) and social identity theory (Tajfel 1981; Tajfel and Turner 1986), as well as foundational research on the role of parental socialization in the development of political ideologies (e.g., Hess and Torney 1967; Jennings and Niemi 1968). As I argue below, engagement with these literatures is integral to a more comprehensive theory of multiracial political attitudes. Furthermore, prior political works have not brought forward the data necessary to test these hypotheses, due in part to the empirical challenges associated with studying the American mixed-race population.

Bringing to bear improved theory and data, this research enhances our understanding of the relationship between race and attitudes by providing new information on the views of biracial people. Bridging diverse and previously unconnected academic literatures, I argue that in considering the consequences of multiracialism, we must assess what it means-historically, politically, and culturally - to be of White and Black parentage in the United States. This entails grappling with the political connotations of crossing rigid racial boundaries, as well as the significance associated with subjective racial labels. I thus frame the political effects of race in terms of two mechanisms: parentage and racial self-identification. I distinguish between these mechanisms by isolating the effects of race that are due to self-identification (e.g., deciding to label oneself as "Black") as well as parents' race (i.e., having interracial parents, as opposed to monoracial parents).

To examine the political attitudes of biracial Americans, I analyze data from a national study of first-year college students. I first assess the sociodemographic backgrounds of the biracial population, and find that most respondents of White-Black parentage now select a multiracial label. I then turn to biracials' political attitudes. Results show that on racial issues, biracials generally hold views akin to the group with which they identify - and that White-Black identifiers tend to share the racial views of Blacks. But the process of growing up both White and Black in a race-conscious society and choosing to embrace both racial labels is also associated with an especially progressive approach to social issues involving gender equality and civil rights. I supplement quantitative data with in-depth interviews to assess two explanations for these findings: the transmission of attitudes from interracial parents to biracial offspring, and the unique life experiences of biracials in the United States.

\section{Defining "Biracial"}

The very words "monoracial" and "biracial" erroneously imply that there are such things as pure, biological races. In reality, race is mutable and contextual (Harris and Sim 2002; Hochschild, Weaver, and Burch 2012). The inherent subjectivity of self-identification raises the question, how should "biracial" be measured?

Given that most Black Americans are of mixed racial ancestry (Davis 2001), I distinguish between individuals who have parents of different races and those who are racially mixed at the level of grandparents or prior generations (Spencer 2004). Here, I define as "biracial" those who identify one parent as White, non-Hispanic and the other parent as Black, non-Hispanic. ${ }^{3}$ I believe that any potential limitations of classifying "biracial" in this manner are outweighed by the sharper interpretations enabled by this approach. In restricting analyses to this population, my aim is not to affirm a perception that the study of race be limited to the Black-White paradigm, or that "biracial" refers principally to people who are White and Black, as opposed to myriad other racial/ethnic combinations (e.g., White-American Indian, Black-Asian). Although this method implicitly presumes that Black parents are "unmixed," it is mitigated to some degree because survey respondents can identify their parents with multiple races (and I exclude such respondents from these analyses).

\section{PRIOR WORK ON MULTIRACIAL POLITICAL ATTITUDES}

The relationship between mixed racial heritage and sociopolitical outlook has long been speculated upon. Many scholars have assumed that people of mixed race are in the center of the racial divide, caught in the middle of two opposing worlds. ${ }^{4}$ In his pivotal work on the psychology of racial hybrids, Park $(1931,538)$ wrote that White-Black biracials represent "a distinct racial category and a separate social class." Considered "too Black" for Whites and "too White" for Blacks, this so-called "marginal man" was not wholly embraced by either race (Park 1928; Stonequist 1935). This theory that biracials are mindful of their dual heritage and not fully incorporated into a single group continues to structure research on the behavior of mixed-race

\footnotetext{
${ }^{3}$ Analyses focus on non-Hispanics to ensure that any opinion differences found across racial groups are attributed to race, and are not masked by Hispanic ethnicity.

${ }^{4}$ This sentiment has also been expressed by Black politicians (Spickard and Burroughs 2000, 247).
} 
Americans (e.g., Fryer Jr., Kahn, Levitt, and Spenkuch 2012; Cheng and Lively 2009).

Other work, in contrast, has argued that part-White biracials tend to share the political views of their minority group. For example, Masuoka (2008) finds that, rather than having attitudes similar to Whites or developing an exclusive mixed-race consciousness, biracials identify more with their marginalized minority racial background. ${ }^{5}$

But due to myriad data barriers, the attitudes of biracial Americans are not well understood. Traditionally, multiracialism research has been limited by nonrepresentative convenience samples (Bowles 1993; Kerwin, Ponterotto, Jackson, and Harris 1993) and issues of classification and measurement (Bracey, Bamaca, and Umana-Taylor 2004; Hochschild and Weaver 2010; Jaret and Reitzes 1999). ${ }^{6}$ Although most political surveys, including the General Social Survey and the American National Election Studies, now employ "mark all that apply" race questions, the sample sizes they yield are usually too small to generate a sufficient number of multiple-race identifiers; to cope with this limitation, researchers often employ methodological approaches that increase the statistical power of the regression analyses, at the expense of analytical clarity. ${ }^{7}$ To compound these problems further, surveys typically do not ask the races of respondents' parents, thus preventing researchers from pinpointing individuals who identify with a single race but are of mixed-race parentage.

In addition to these data limitations, almost nothing is known about multiracials' nonracial attitudes, because research (e.g., Masuoka 2011) tends to focus solely on the racial views of this group. This approach discounts the many nonracial topics on which Blacks and Whites have opposing attitudes, such as capital punishment or discrimination of gays (Kinder and Sanders 1996). This may explain why researchers alternatively find that biracials are politically in between Whites and Blacks on certain dimensions, but akin to Blacks on others. Improving our understanding of the political ramifications of multiracialism thus requires better data as well as more nuanced theory and empirical analyses.

\footnotetext{
${ }^{5}$ Hochschild and Weaver (2007) similarly find that Blacks' perceptions of discrimination and linked fate do not tend to vary by skin color, though they do not measure the views of biracials specifically. ${ }^{6}$ For example, when prompted, some respondents will say that they "belong to more than one racial group," but when asked to specify the groups to which they belong, relatively few list more than one race (Masuoka 2008).

${ }^{7}$ For instance, Masuoka $(2008,258)$ codes respondents in a manner that double counts mixed-race individuals, which she acknowledges is "problematic" but argues will enable more reliable analyses than the alternative of disaggregating respondents into "extremely small samples." Jaret and Reitzes (1999) combine different multiple-race subgroups into a single "multiracial" sample, which may obscure the significant sociodemographic differences that exist across across biracial subgroups (Davenport 2016).
}

\section{THEORY AND ARGUMENT}

The product of an unconventional union, Americans of White-Black parentage constitute a distinct group. Traditionally, these individuals were viewed as a reflection of the intimate crossing of a strict racial periphery and a threat to the American racial order (Davis 2001; Myrdal 1944). Although the U.S. Supreme Court overturned anti-miscegenation laws in 1967, the rate of White-Black intermarriage is hundreds of times lower than chance would predict (Fryer 2007; Rosenfeld 2007) and public support for these marriages is lower than for other types of interracial marriages (Wang 2012). White-Black married couples are also more likely to divorce than endogamous White couples (Bratter and King 2008; Zhang and Van Hook 2009).

The implications of interracial parentage are noteworthy for the construction of biracials' attitudes because families play an integral role in initiating children into politics (Greenstein 1965; Hess and Torney 1967). As they grow and develop, children are regularly exposed to cues that signal and push them towards their parents' political orientations, even beyond other social influences such as local political climate (Jennings, Stoker, and Bowers 2009). While we understand little about the politics of interracial couples (and even less about the orientations of single parents who have biracial children) ${ }^{8}$ the decision to enter into an interracial relationship in the first place reflects some degree of social progressivism (Banks 2011). White-Black couples also grapple with unique cultural conflicts that heighten their awareness of prejudice (Dalmage 2000; Root 2001), and these experiences may bolster a distinctly liberal political belief system that is directly transmitted to biracial children.

Aside from the impact of their parents' ideology, it would seem that biracial individuals are shaped by their own experiences straddling the White-Black racial divide in American society. People of mixed-race ancestry often spend years grappling with their identities (Bailey 2008; DaCosta 2007; Rockquemore and Brunsma 2008) and have the option of identifying in a number of ways, including now with multiple groups. Racial labels are a product of social and economic processes, as well as interpersonal interactions and encounters (Bratter 2007; Campbell 2007; Davenport 2016).

Biracials' chosen racial group identifications should be a meaningful barometer of their political attachments because political solidarity develops from the construction of subjective group identities. Identification requires both awareness of one's membership in the group, as well as a psychological attachment to the group (Tajfel 1981; Tajfel and Turner 1986), and group identifiers pay closer attention to those issues most central to the group's interests (Conover 1984). The meanings associated with biracials' chosen racial

\footnotetext{
8 This limitation is due to a lack of generalizable data. In 2001, Kaiser, Harvard, and the Washington Post conducted a "Survey of Biracial Couples," but the study asked no policy questions and only interviewed interracial couples currently married or living together.
} 
identification thus provide context for their political outlooks. ${ }^{9}$

Biracials who identify as "White-Black" are simultaneously distinguishing themselves from each of their component backgrounds while also incorporating both into a single self-concept. ${ }^{10} \mathrm{~A}$ White-Black identification connotes both an in-between racial status and all-encompassing one. Identification as part-Black reflects subjective membership in a minority group, while identification as part-White reflects the embracing of White heritage as part of oneself - a pointed declaration given decades of hypodescent. The label "WhiteBlack" is a break from the status quo and intimates a perspective on race that is unconfined by traditions and expectations - and potentially a political outlook that is similarly open minded.

Whereas a multiple-race label is inclusive, singular racial labels such as "Black" and "White" are exclusive. For Black Americans, the legacy of slavery, discrimination, and inequality help explain the construction of political unity (Du Bois 1903a; Shelby 2005). Blacks take a collective approach to politics, believing that what happens to the race has implications for the individual (Dawson 1994; 2001). In sharp contrast, race is not as salient for Whites as a group because they are much less likely to experience intolerance or injustice. By virtue of their majority status and social position, Whites are typically afforded the ability to not think of themselves in terms of race at all (Flagg 1993; HaneyLopez 2006).

This brings me to some hypotheses regarding biracials' political views:

First, on issues of race, singular-identifying biracials will express attitudes most akin to monoracials who share their racial label. In their decision to identify as Black, biracials express a linked fate with Black Americans and an increased recognition of racial disparities. Comparatively, biracials who label themselves as singularly White contradict racial norms of hypodescent (Davis 2001; Haney-Lopez 2006) and reflect a closer connection with their majority race. White identification is hence illustrative of weak attachments to the Black American community. Identification as WhiteBlack signifies both identification with a minority group and a socially progressive approach to race, suggesting that these biracials will express strong support for racial policies, at levels more comparable to Blacks.

Second, on nonracial social attitudes, biracialsregardless of identification - will evince greater support than their monoracial peers on issues involving

\footnotetext{
${ }^{9}$ Elsewhere (Davenport 2016), I disentangle the construction of biracials' identification; those results indicate that significant predictors of identification include gender, parents' socioeconomic status, religion, and parents' race/gender. Neighborhood racial and economic composition also explain identification; all else equal, living in a more affluent community pushes biracials away from a Black identification and towards a "lighter" one (either White or WhiteBlack), and living in a more Black community pushes biracials towards a Black label, away from a White one.

10 The label "White-Black" is a designation I have chosen to reflect the marking of both races by a biracial respondent. The ordering of the two races (i.e., White before Black) does not necessarily reflect a respondent's stronger connection to a particular group.
}

equality and civil liberties. These left-leaning opinions will be shaped by the passage of liberal social views from their interracial parents, as well as their own individual encounters as members of a marginalized minority group. Biracials who choose to identify as White-Black will express particularly progressive views on these issues, as the rejection of norms encapsulated in this racial label reflects a distinct parting from sociopolitical conventions.

\section{DATA AND METHODS}

To assess the political attitudes of biracial Americans, I examine data from The Freshman Surveys, which are collected by the Cooperative Institutional Research Program (CIRP) at UCLA's Higher Education Research Institute (HERI). Each year, the Freshman Surveys are completed by hundreds of thousands of firstyear college students across the United States. The surveys are given during orientation or registration at hundreds of higher learning institutions, including twoyear and four-year colleges; research universities; public, private, and religious schools; single-sex schools; and historically Black colleges and universities (Sax et al. 2001; 2002; 2003). Detailed information on the Freshman Survey methodology is provided in the Appendix.

These data enable us to overcome many limitations of prior work. Importantly, the inclusion of political questions set the Freshman Surveys apart from other large sample datasets often used to study mixed-race Americans. ${ }^{11}$ Especially notable is the Freshman Survey's large sample size; pooling data from the three years in which students were asked their parents' races (2001-2003) produces a sample of several thousand respondents of White-Black parentage. I also append to these data three census sociodemographic measures that are omitted in other large surveys of mixed-race individuals: respondent median income, percent Black, and population density at the home zip-code level. At present, the Freshman Surveys are the only representative study that permits multiple-race identification, includes the race of respondents' parents, asks political questions, and has a large sample of mixed-race respondents. ${ }^{12}$

Broadly speaking, since the mixed-race population is relatively young, focusing on individuals in late adolescence and early adulthood helps generate a larger multiracial sample (Fryer Jr. et al. 2012). There are, however, some limitations to concentrating on firstyear college students. Notably, these data cannot speak

\footnotetext{
${ }^{11}$ Examples include the Census Public Use Microdata Sample (Bratter 2007; Gullickson and Morning 2011; Kanaiaupuni and Liebler 2005; Qian 2004); the Census 2000 Redistricting Summary File (Brunsma 2006); the Current Population Survey (Campbell 2007); and the Early Childhood Longitudinal Study (Brunsma 2005).

12 To my knowledge, only two other studies - the Kaiser/Harvard/ Washington Post "Race and Ethnicity in 2001" survey and Wave III of the National Longitudinal Study of Adolescent Health-are nationally representative, include parents' races, permit multiplerace identification, and include political questions. Unfortunately, the White-Black biracial sample sizes in each of these surveys is very small.
} 


\section{TABLE 1. Racial Parentage as a Predictor of Biracials' Identification}

\begin{tabular}{lccc}
\hline \multirow{2}{*}{ Self-Identification } & \multicolumn{3}{c}{ Race of Parents } \\
\cline { 2 - 4 } & Both White & Both Black & One White, One Black \\
\hline White & $99.97 \%$ & $0.07 \%$ & $7.0 \%$ \\
Black & 0.02 & 99.87 & 38.4 \\
White-Black & 0.01 & 0.06 & 54.6 \\
\hline$N$ & 854,025 & 79,570 & 3,448 \\
\hline
\end{tabular}

to the attitudes of the nearly one in ten people who drop out of high school. ${ }^{13}$ But because two-thirds of students who do graduate high school enroll in college following their senior year (National Center for Education Statistics 2014; Norris 2014), examining those who have recently arrived to college should still capture a sizable fraction of this age group. The inclusion of community colleges in this study also makes for a more socioeconomically diverse set of respondents. Furthermore, unlike other multiracialism studies that utilize census data (e.g., Xie and Goyette 1997; Qian 2004), the Freshman Surveys include biracial children whose parents are unmarried, which additionally helps ensure a heterogeneous set of samples, in light of the correlation between marital status and social class (McLeod and Kessler 1990).

The two primary predictive variables of interest here are respondent parentage and racial identification. I consider respondents to be "monoracial" if they have either two singularly White parents or two singularly Black parents. Respondents are "biracial" if they report one parent as singularly White and the other parent as singularly Black. Among those who report biracial parentage, I disentangle self-identification with one of three racial groups: White, Black, and WhiteBlack. ${ }^{14}$ In total, five different groups are examined: Monoracial Whites $(n=853,773)$, Biracial Whites $(n=$ 241), Biracial White-Blacks $(n=1,884)$, Biracial Blacks $(n=1,323)$, and Monoracial Blacks $(n=79,469) .{ }^{15}$

\footnotetext{
13 This represents the percentage of 16- to 24 -year-olds who are not enrolled in school and have not earned a high school diploma or equivalent (National Center for Education Statistics 2014).

${ }^{14}$ I exclude "Other Race" identifiers from these analyses both for purposes of substantive political importance and analytical clarity Since the 2000 Census change debate centered around the political ramifications associated with explicit multiple-race labels, I focus here on the attitudes of biracials who identify with one or both of their parent racial groups, as opposed to those who see themselves as part of some "other" group.

15 While the sample of Biracial Whites may seem small, it is actually very large relative to Biracial White samples in other studies, which can number in the single digits (e.g., Khanna 2011; Rockquemore and Brunsma 2008). Because there is currently no national baseline to which we can compare, it is impossible to know for certain exactly how representative and generalizable this sample of Biracial Whites is. But the proportion of biracials who identify as White here is within the range of other studies, which find rates of White identification as low as 3 percent (Khanna 2011) and as high as 15 percent (Brunsma 2005).
}

\section{Descriptive Statistics}

I begin by breaking down the three parentage groups (Monoracial White, Monoracial Black, and Biracial) by their chosen identification with one of three racial categories (White, Black, and White-Black).

Table 1 shows that, unsurprisingly, almost all respondents of monoracial parentage-over 99 percentidentify as either singularly White or singularly Black. In contrast, respondents of mixed parentage exhibit much less constraint in their identification, with 55 percent identifying as White-Black. ${ }^{16}$ That most individuals of White-Black parentage do not self-identify as singularly Black indicates that the one-drop rule no longer defines group belonging for young biracials. However, this lack of a singular Black label does not necessarily reflect a dissociation from minority ancestry, and the small percentage of biracials who opt to call themselves White demonstrates that the bounds of Whiteness essentially remain impenetrable for this group. Instead, most biracials are choosing to present themselves as belonging to multiple groups - both White and Black.

Table 2 displays group differences with respect to gender, region, parents' marital status, religion, and neighborhood type. ${ }^{17}$ Biracials, regardless of racial identification, are most likely to live in the Pacific West. While a plurality of Monoracial Blacks live in the South, White-Black identifiers are the least likely to live in that region, an unsurprising finding given the South's history of strict adherence to the one-drop rule (Davis 2001). The five racial groups also grow up in different neighborhoods. Relative to Monoracial Whites, Monoracial Blacks are much more likely to come from neighborhoods that are in the bottom median income quartile, and areas that are more densely populated and more Black. Biracials' identifications correspond to their neighborhood context. Compared to Biracial Blacks, Biracial Whites grow up in neighborhoods that are much more affluent, less densely populated, and less Black - while Biracial White-Blacks grow up in

\footnotetext{
${ }^{16}$ Additional descriptive statistics on the biracial sample are presented in the Appendix.

${ }^{17}$ Region and neighborhood type are based on the respondent's home state and zip code, respectively, not where their college is located. The six religious indicator variables - Baptist, Catholic, Other Christian, Jewish, Some Other Religion, and No Religion-were coded as such because these religions and denominations are the largest in terms of size and/or are the most racially homogeneous.
} 


\begin{tabular}{|c|c|c|c|c|c|}
\hline & \multicolumn{5}{|c|}{ Parentage and Self-Identification } \\
\hline & $\begin{array}{l}\text { Monoracial } \\
\text { White }\end{array}$ & $\begin{array}{l}\text { Biracial } \\
\text { White }\end{array}$ & $\begin{array}{c}\text { Biracial } \\
\text { White-Black }\end{array}$ & $\begin{array}{l}\text { Biracial } \\
\text { Black }\end{array}$ & $\begin{array}{c}\text { Monoracial } \\
\text { Black }\end{array}$ \\
\hline Female & $55.5 \%$ & $48.1 \%$ & $59.8 \%$ & $44.1 \%$ & $61.9 \%$ \\
\hline \multicolumn{6}{|l|}{ Region } \\
\hline Pacific & 8.6 & 16.9 & 19.4 & 14.7 & 5.9 \\
\hline South & 25.7 & 24.0 & 18.8 & 26.5 & 46.1 \\
\hline Mountains/Plains & 5.7 & 7.6 & 5.2 & 6.4 & 1.1 \\
\hline Northeast & 36.3 & 35.1 & 34.1 & 31.4 & 29.6 \\
\hline Midwest & 23.7 & 16.4 & 22.5 & 21.0 & 17.3 \\
\hline \multicolumn{6}{|c|}{$\begin{array}{l}\text { Neighborhood median } \\
\text { income }\end{array}$} \\
\hline Lowest quartile & 21.9 & 23.1 & 28.1 & 35.5 & 49.3 \\
\hline Highest quartile & 26.7 & 26.2 & 17.0 & 14.5 & 9.3 \\
\hline \multicolumn{6}{|c|}{$\begin{array}{l}\text { Neighborhood population } \\
\text { density }\end{array}$} \\
\hline Lowest quartile & 29.2 & 24.0 & 14.0 & 18.3 & 15.0 \\
\hline Highest quartile & 17.7 & 26.7 & 38.9 & 33.6 & 44.8 \\
\hline \multicolumn{6}{|c|}{$\begin{array}{l}\text { Neighborhood percent } \\
\text { Black }\end{array}$} \\
\hline Lowest quartile & 29.5 & 21.7 & 9.3 & 10.4 & 0.8 \\
\hline Highest quartile & 18.2 & 27.2 & 44.8 & 44.2 & 84.6 \\
\hline \multicolumn{6}{|c|}{ Parents' marital status } \\
\hline Married & 76.9 & 56.4 & 48.8 & 46.7 & 42.6 \\
\hline Unmarried & 23.1 & 43.6 & 51.2 & 53.3 & 57.4 \\
\hline \multicolumn{6}{|l|}{ Religion } \\
\hline Baptist & 8.6 & 9.9 & 13.5 & 19.9 & 45.3 \\
\hline Roman Catholic & 31.1 & 15.9 & 17.0 & 15.9 & 7.1 \\
\hline Other Christian & 36.2 & 33.5 & 34.5 & 33.0 & 31.9 \\
\hline Jewish & 3.9 & 7.3 & 1.7 & 2.0 & 0.1 \\
\hline Other religion & 3.1 & 8.6 & 5.1 & 5.6 & 6.4 \\
\hline No religion & 17.1 & 24.9 & 28.4 & 23.6 & 9.2 \\
\hline$N$ & 853,773 & 241 & 1,884 & 1,323 & 79,469 \\
\hline
\end{tabular}

areas that are only somewhat more affluent and densely populated, and about as Black.

Approximately half of biracials report having married parents, which is more comparable to that of Monoracial Blacks than Monoracial Whites. As a group, biracials are significantly less religious than their monoracial counterparts, and White-Black identifiers are particularly likely to be nonreligious. Among the three biracial groups, White identifiers are the most likely to follow Judaism, a predominantly White religion (Pew 2013), while Black identifiers are most likely to be Baptist, a religion with which Black Americans tend to affiliate (Kosmin and Keysar 2009).

Figure 1 presents an overview of socioeconomic characteristics across racial groups. The patterns of family income are illustrated in the first graph, which shows that the biggest disparity for family income exists between Monoracial Whites and Monoracial Blacks. Biracials are in the middle of these two groups, and their income is correlated with identification; Biracial Whites are most similar to Monoracial Whites, Biracial
Blacks are most like Monoracial Blacks, and WhiteBlacks fall in between. Father's and mother's level of education follows roughly similar racial group patterns. These findings corroborate research showing that White-Black interracial couples are of higher socioeconomic status than endogamous Black couples (Wang 2012).

Overall, these significant demographic differences across groups reinforce the importance of accounting for confounding factors in the analyses of political attitudes, particularly that of religion, which may structure opinions regarding whether government should have the capacity to regulate private behavior (Beck and Jennings 1991).

\section{Regression Models}

In evaluating biracials' political attitudes, I run ordered logistic regressions in which the dependent variables of interest are views on explicitly racial issues (the degree to which one believes that racial discrimination 


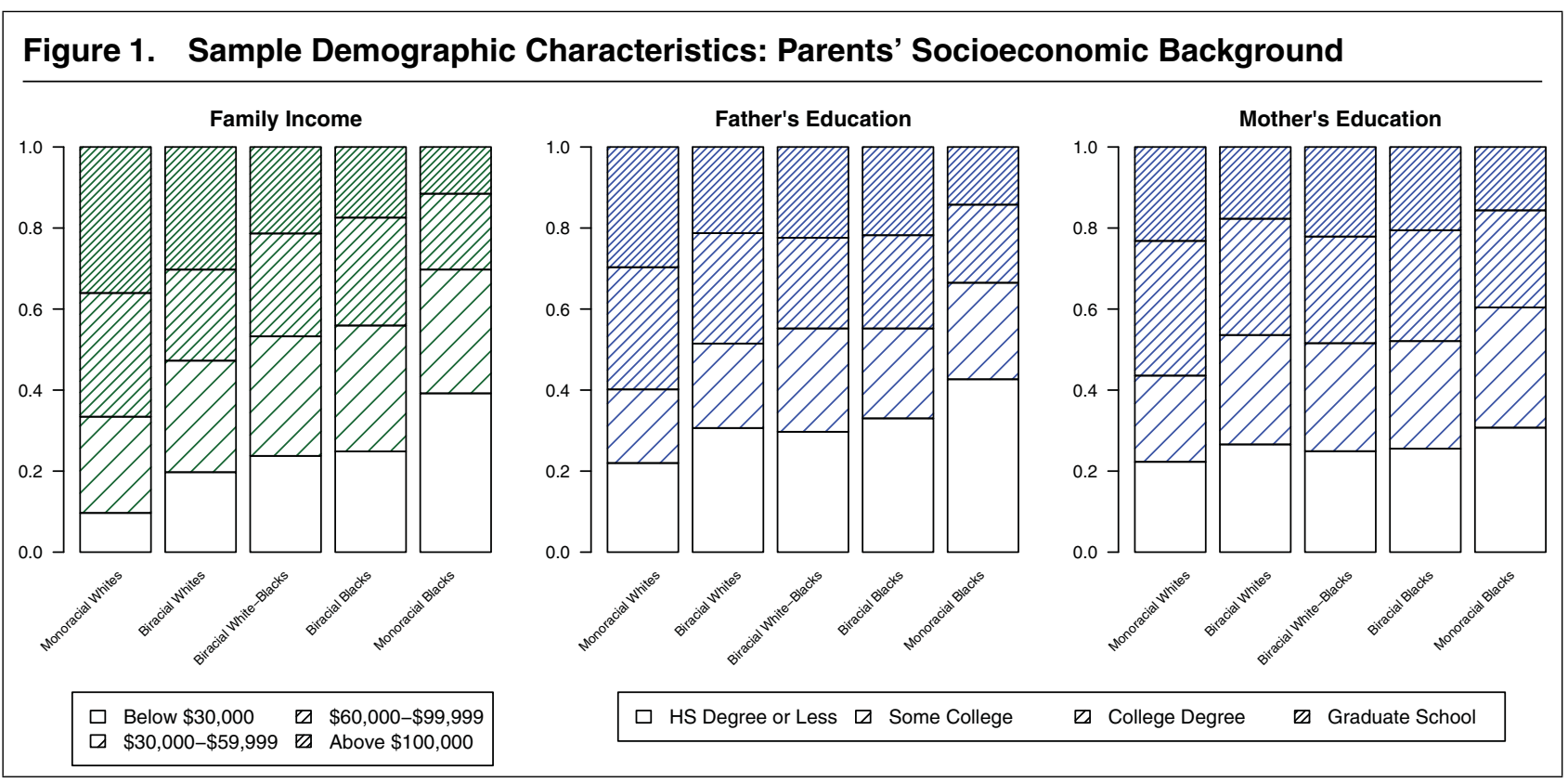

continues to be a problem, the level of importance placed on promoting racial understanding, and support for affirmative action in college admissions); implicitly racial issues (support for criminals' rights, the death penalty, and gun control); and nonracial social issues (abortion, whether the activities of married women should be limited to the home and family, and same-sex marriage). ${ }^{18}$ Responses are coded from 0 to 1 such that higher values reflect more politically liberal views.

Regressions include covariates for gender, parents' education, family income, parents' marital status, religion, region, neighborhood (zip code median income, proportion Black non-Hispanic, and population density), and year surveyed. In order to assess whether there are differences in attitudes within racial identification groups by parentage, separate regressions are run for White identifiers, Black identifiers, and biracials (of any identification). For White identifiers and Black identifiers, I employ matching before each regression to better ensure comparability along demographic characteristics. ${ }^{19}$ For ease of interpretation, I use the ordered logistic regression estimates to generate responses on the 0 to 1 scale and present the predicted differences in responses between the racial

\footnotetext{
${ }^{18}$ Like many social policies, access to abortion may disproportionately affect racial and ethnic minorities. However, the topic of abortion does not generally evoke as strong racial stereotypes as, for instance, crime, and is arguably a more gendered issue than a racial one (Luker 1984).

${ }^{19}$ I exact-match on gender, year, and region; and nearest-neighbormatch on parents' education, income, parents' marital status, religion, and neighborhood effects. I employ an ordered logit model because the dependent variables are ordinal, though results are robust to alternative model specifications and methodological approaches (including ordered logit models without matching, and OLS models with and without matching).
}

groups. Results shown are racial outcomes, though full tables of ordered logistic regressions, as well as all question wording and variable coding, are in the Appendix. ${ }^{20}$

A Note on Interpretation. Since parents' race naturally precedes children's race, the effects of parentage can be interpreted as causally prior to both children's self-identification and political attitudes. Thus any differences in political views between biracial and monoracial respondents that are found in a regression framework can be attributed to differences in parentage. More complex is the relationship between biracials' self-identification and their political attitudes. These observational data do not enable me to make causal claims about the role of racial identification on attitudes. While the regression analyses presented designate self-identification as one predictor of political attitudes, results should not be taken to mean that identification leads to attitudes. Rather, self-identification and political views may constitute a cluster of intertwined social beliefs, because the labels that some biracials choose to adopt can be a consequence-rather than a cause - of holding a particular view. For example, negative affect towards a racialized policy like welfare (Gilens 1999) may engender feelings of resentment towards Blacks as a group, and push biracials away from a Black identification of any kind (though it does seem less likely that nonracial attitudes, such as

\footnotetext{
${ }^{20}$ As the regression tables indicate, significance of covariates often depends on the racial group and political issue, though some consistent covariate patterns do emerge. In particular, gender is generally the most substantively significant predictor of attitudes; net of all other variables, on every issue and across racial groups, women express more liberal opinions than men. Higher family income and parents' education - both father's and mother's-also tend to have a liberalizing effect.
} 
TABLE 3. Attitudes Towards Explicitly Racial Issues

\begin{tabular}{|c|c|c|c|c|c|}
\hline & $\begin{array}{c}\text { Monoracial } \\
\text { White }\end{array}$ & $\begin{array}{l}\text { Biracial } \\
\text { White }\end{array}$ & $\begin{array}{c}\text { Biracial } \\
\text { White-Black }\end{array}$ & $\begin{array}{c}\text { Biracial } \\
\text { Black }\end{array}$ & $\begin{array}{c}\text { Monoracial } \\
\text { Black }\end{array}$ \\
\hline Racism is a major problem & $77.6 \%$ & $77.4 \%$ & $90.6 \%$ & $89.1 \%$ & $88.8 \%$ \\
\hline Promote racial understanding & 26.0 & 36.7 & 58.9 & 59.5 & 57.1 \\
\hline Support affirmative action & 44.4 & 52.9 & 71.7 & 75.0 & 75.7 \\
\hline
\end{tabular}

Figure 2. Regression Estimates of Differences in Attitudes Towards Explicitly Racial Issues

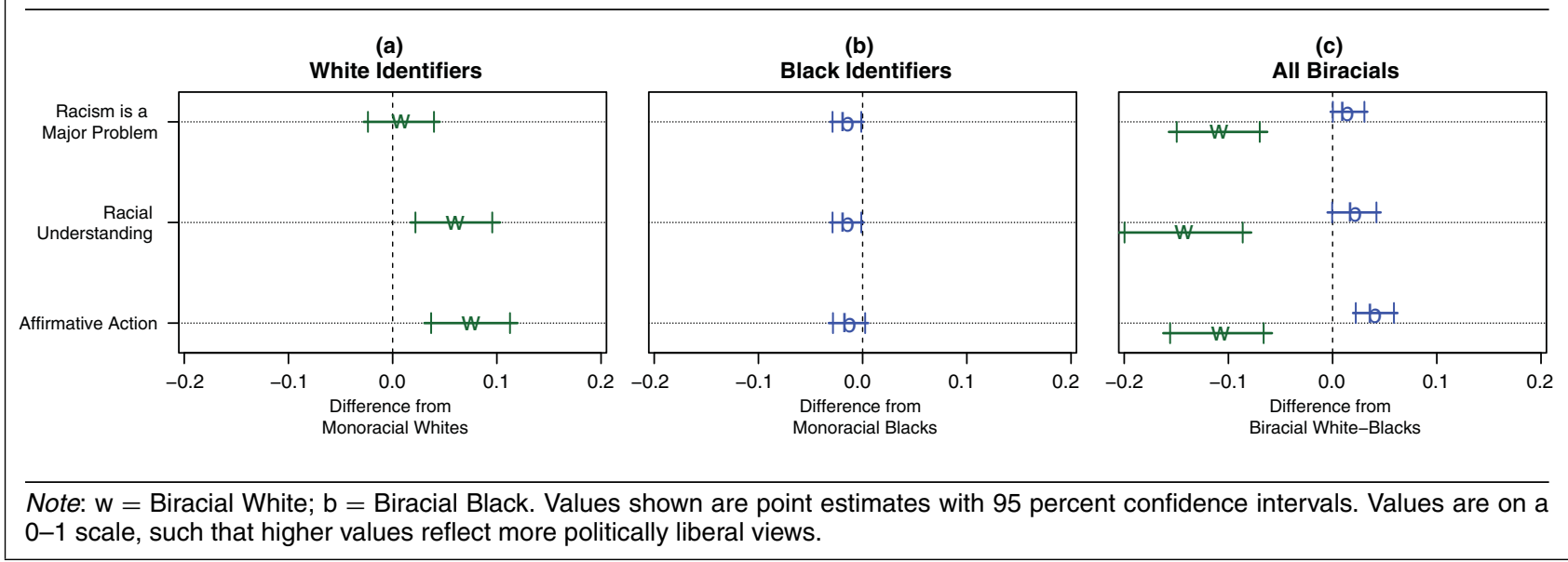

feelings towards same-sex marriage or abortion, would shape racial labeling). Recognizing that identification is likely interconnected with political ideology, I thus interpret political attitudes as being associated withand not necessarily the result of-biracials' chosen identifications.

\section{RESULTS}

\section{Explicitly Racial Attitudes}

Table 3 displays opinion estimates on explicitly racial issues for each identification group. In line with prior research, Monoracial Whites express the least support for racial issues and are 30 percentage points less supportive than Monoracial Blacks of affirmative action and less likely to think it is important to promote racial understanding. As hypothesized, biracials' subjective group identification is highly correlated with their racial policy attitudes; Biracial Whites are most akin to Monoracial Whites, while Biracial White-Blacks and Blacks appear no different from Monoracial Blacks.

Figure 2 presents the regression estimates of racial attitude differences. Panel (a) shows differences in attitudes between White identifiers, panel (b) shows differences between Black identifiers, and panel (c) compares the three biracial groups, by self-identification. As panel (a) illustrates, when other correlates are held constant, Biracial Whites are as likely as Monoracial Whites to believe that racism is a major problem. But on the other two racial measures, having a Black parent significantly shapes Biracial Whites' opinions; relative to Monoracial Whites, Biracial Whites are 6 percent more likely to believe that it is important to help promote racial understanding and 7 percent more likely to support affirmative action in college admissions. Thus while their identification reflects the absence of a minority label, Biracial Whites do seem to be influenced by their minority parentage. In contrast to Whites, there is no substantive difference in racial attitudes among Black identifiers, as panel (b) illustrates.

Panel (c) shows that despite their identification as partly White, Biracial White-Blacks evince racial attitudes that are mostly comparable to those of Biracial Blacks, all else equal. At roughly similar rates, Biracial White-Blacks and Biracial Blacks agree that racial discrimination is a problem and believe it is important to promote racial understanding. However, biracials who identify as White are 10 to 15 percent less likely to subscribe to these views, suggesting that the choice to call oneself White is also correlated with less liberal racial attitudes.

In sum, on matters explicitly racial in nature, labeling oneself as at least partly Black is a key correlate of liberal attitudes and a greater commitment to racial progress. All told, these results generally indicate that 
TABLE 4. Attitudes Towards Implicitly Racial Issues

\begin{tabular}{llllll}
\hline & $\begin{array}{c}\text { Monoracial } \\
\text { White }\end{array}$ & $\begin{array}{c}\text { Biracial } \\
\text { White }\end{array}$ & $\begin{array}{c}\text { Biracial } \\
\text { White-Black }\end{array}$ & $\begin{array}{c}\text { Biracial } \\
\text { Black }\end{array}$ & $\begin{array}{c}\text { Monoracial } \\
\text { Black }\end{array}$ \\
\hline Criminals' rights & $36.9 \%$ & $41.6 \%$ & $47.4 \%$ & $46.0 \%$ & $46.0 \%$ \\
Death penalty & 32.0 & 37.3 & 41.9 & 38.8 & 42.4 \\
Gun control & 76.4 & 77.1 & 85.3 & 83.4 & 87.9 \\
\hline
\end{tabular}

Note: Percentages indicate support for criminals' rights, agreement that the death penalty should be abolished, and support for stronger federal gun control laws.

\section{Figure 3. Regression Estimates of Differences in Attitudes Towards Implicitly Racial Issues}

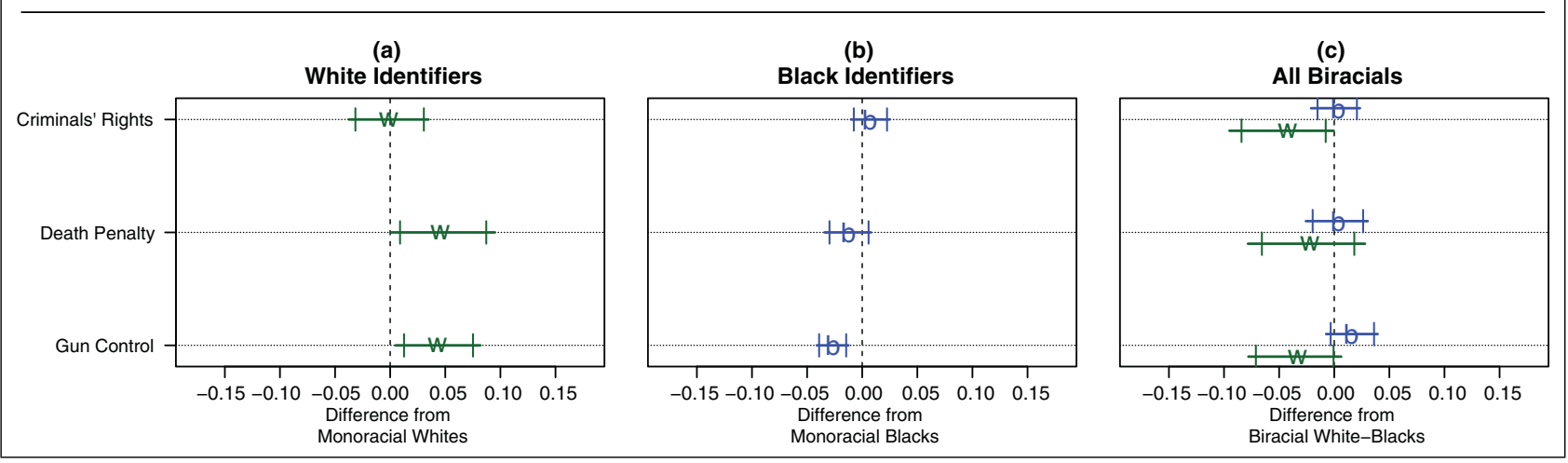

biracials' explicitly racial attitudes tend to mirror those held by the racial group with which they identify. ${ }^{21}$

\section{Implicitly Racial Attitudes}

Table 4 shows attitudes on the implicitly racial issues of crime policy-criminals' rights, the death penalty, and gun control. Across these issues, Monoracial Blacks are again the most liberal and Monoracial Whites the most conservative. However, the range in attitudes is not as wide, and often ten or fewer percentage points. Findings on implicitly racial issues parallel those on explicitly racial issues. That is, singular-identifying biracials exhibit views that are most similar to their Monoracial White and Black counterparts; Biracial Whites' attitudes are most analogous to those held by Monoracial Whites, whereas Biracial Blacks are primarily akin to Monoracial Blacks. Biracial White-Blacks are again largely indistinguishable from Monoracial Blacks, suggesting that Biracial White-Blacks share a racial awareness with their minority-identified counterparts.

These findings hold up in the ordered logistic regression models in Figure 3. Once other sociodemographic factors are accounted for, singular-identified biracials are not much different from monoracials who share their identification, though results also suggest that the political effects of biracial parentage can endure

\footnotetext{
$\overline{21}$ These results also support Masuoka's (2008) finding that racial attitude differences are greater between mixed-race identifiers and Whites than between mixed-race identifiers and Blacks.
}

even when individuals do not label themselves as such. This is evident in panel (a), which shows that-all else equal-Biracial Whites express greater opposition to the death penalty and greater support for gun control than Monoracial Whites. This finding is also visible in panel (b), which illustrates Biracial Blacks' slightly lower support for gun control than Monoracial Blacks. Overall, though, biracials' implicitly racial attitudes are again a function of their chosen identification - with White-Black identifiers looking a lot like Blacks.

\section{Nonracial Attitudes}

Table 5 presents opinions on nonracial social attitudes: abortion, support for married women working outside the home and family, and support for same-sex couples being afforded the right to legal marital status. Here, Biracial White-Blacks distinguish themselves as a uniquely progressive group, particularly on married women's place in society and same-sex marriage. On abortion, biracials - regardless of identificationexpress the most liberal views. Monoracial Blacks, in contrast, are the most conservative group in every area; their support ranges from 12 to 20 points lower than that expressed by Biracial White-Blacks.

Figure 4 reveals that these effects persist in the presence of statistical adjustments. As with racial issues, Biracial Whites' views are again generally similar to those of Monoracial Whites. For White identifiers, differences in racial parentage do not necessarily lead to differences in social attitudes; for two of the three issues under examination (abortion and same-sex 
TABLE 5. Attitudes Towards Nonracial Issues

\begin{tabular}{|c|c|c|c|c|c|}
\hline & $\begin{array}{l}\text { Monoracial } \\
\text { White }\end{array}$ & $\begin{array}{l}\text { Biracial } \\
\text { White }\end{array}$ & $\begin{array}{c}\text { Biracial } \\
\text { White-Black }\end{array}$ & $\begin{array}{c}\text { Biracial } \\
\text { Black }\end{array}$ & $\begin{array}{c}\text { Monoracial } \\
\text { Black }\end{array}$ \\
\hline Abortion rights & $54.5 \%$ & $65.1 \%$ & $64.1 \%$ & $61.1 \%$ & $51.9 \%$ \\
\hline Married women & 80.9 & 74.2 & 86.4 & 79.2 & 71.9 \\
\hline Same-sex marriage & 59.2 & 61.4 & 70.0 & 62.0 & 49.3 \\
\hline
\end{tabular}

\section{Figure 4. Regression Estimates of Differences in Attitudes Towards Nonracial Issues}

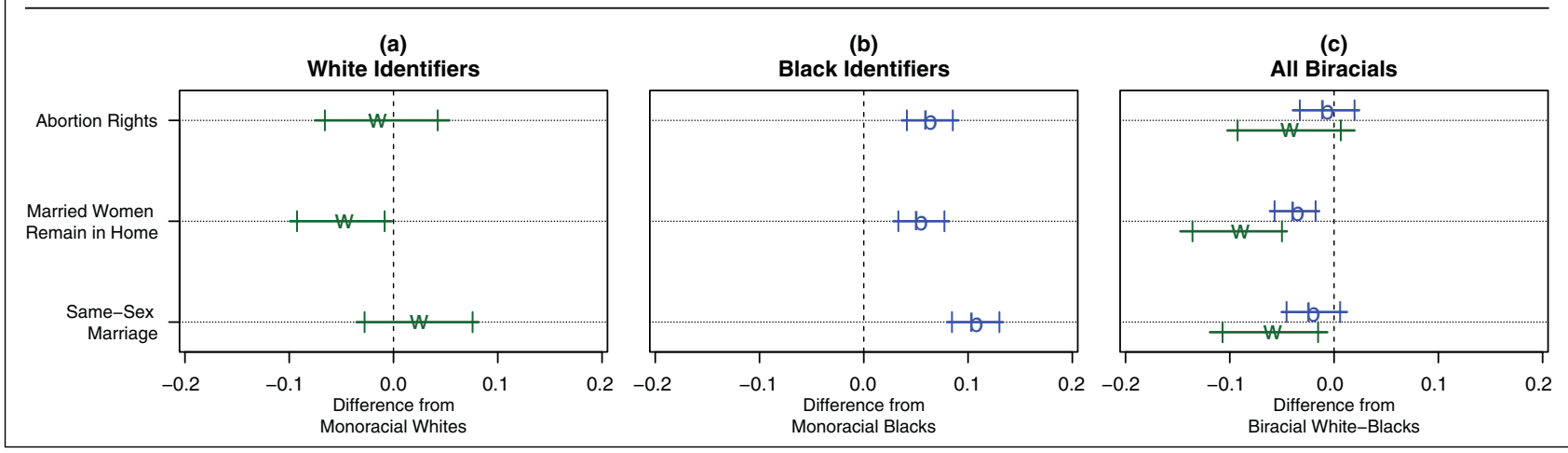

marriage), Biracial Whites share the views of Monoracial Whites.

This is not the case for respondents identifying as Black. Among Black identifiers, net of all covariates, parentage is consistently and strongly predictive of opinion. Panel (b) shows that Biracial Blacks are significantly more liberal than Monoracial Blacks on all nonracial issues. The largest difference in opinion here has to do with same-sex marriage; Biracial Blacks are 10 percent more approving than their Monoracial Black peers, all else equal. Thus despite their congruous racial identification, Blacks of biracial parentage possess markedly less traditional social attitudes than Blacks of monoracial parentage, even when accounting for many other factors within a regression framework.

Panel (c) shows that on abortion, all three groups have similar levels of support, while on attitudes towards married women, biracial White-Blacks express the most progressive opinions. Biracial Blacks' attitudes are statistically indistinguishable from those of Biracial White-Blacks on same-sex marriage. Biracials' unique support for this issue should not be surprising, given the parallels between same-sex marriage and interracial marriage: both policies have been framed as civil rights issues involving the legal recognition of romantic unions considered to be socially transgressive (Eskridge Jr. 1993; Haider-Markel and Joslyn 2005).

Taken together, these results indicate that on nonracial social matters, individuals of biracial parentage who identify as racial minorities (i.e., as part-Black) express more liberal views than their monoracial counterparts.

\section{Explaining Biracials' Political Opinions}

This article's findings clarify where biracials of WhiteBlack parentage fall on several political issues. Results indicate that by overlooking the role of racial identification and parentage, prior research on the political attitudes of mixed-race Americans has simplified a complex social phenomenon. But what accounts for White-Black identifiers' liberal racial and social attitudes?

Here, I address the role of parental influences and personal experiences in greater depth. In doing so, I supplement the Freshman Survey findings with indepth interviews of biracial college students to help disentangle the mechanisms at work. ${ }^{22}$

Research on parental socialization has shown that children generally have value orientations that are similar to their parents (Hyman 1959; Thomas 1971; Troll, Neugarten, and Kraines 1969). Values including individualism and materialism are transmitted from parents to children due to the inheritance of socioeconomic status, the propensity of children to model their parents' attributes, and parent-child relationship type (Bengtson, Biblarz, and Roberts 2002). Yet parents often do not transmit specific attitudes to their children (Connell 1972; Jennings and Niemi 1968; Niemi and Jennings 1991). Adolescents tend to be more

\footnotetext{
${ }^{22}$ Interviews were conducted in Fall and Winter 2013-2014. Participants were undergraduates at colleges and universities in the San Francisco Bay area. Full details on the sample and methodology are available in the Appendix.
} 


\begin{tabular}{|c|c|c|c|c|c|c|c|c|c|}
\hline & $\begin{array}{l}\text { Racism } \\
\text { Problem }\end{array}$ & $\begin{array}{l}\text { Promote } \\
\text { Racial }\end{array}$ & $\begin{array}{c}\text { Aff } \\
\text { Action }\end{array}$ & $\begin{array}{l}\text { Criminal } \\
\text { Rights }\end{array}$ & $\begin{array}{l}\text { Death } \\
\text { Penalty }\end{array}$ & $\begin{array}{l}\text { Gun } \\
\text { Control }\end{array}$ & Abortion & $\begin{array}{c}\text { Same-Sex } \\
\text { Marriage }\end{array}$ & $\begin{array}{l}\text { Married } \\
\text { Women }\end{array}$ \\
\hline \multicolumn{10}{|l|}{ Parents' background } \\
\hline Black mother & & & & & & $*$ & & & \\
\hline Unmarried parents & & & & $*$ & & $*$ & * & $*$ & \\
\hline \multicolumn{10}{|l|}{ Father's education } \\
\hline $\begin{array}{l}\text { Some college } \\
\text { College } \\
\text { Grad school }\end{array}$ & & & & $*$ & & & & & \\
\hline \multicolumn{10}{|l|}{ Mother's education } \\
\hline Some college & & & & & & & & & $*$ \\
\hline College & & & $*$ & & $*$ & & & & $*$ \\
\hline Grad school & $*$ & & $*$ & $*$ & $*$ & & & & $*$ \\
\hline \multicolumn{10}{|l|}{ Income } \\
\hline Family & $*$ & & & & & & $*$ & $*$ & \\
\hline Median zip code & & & $*$ & & & & $*$ & & \\
\hline $\begin{array}{l}\text { Religiously affiliated } \\
\text { Environment }\end{array}$ & * & * & * & $*$ & $*$ & $*$ & $*$ & $*$ & $*$ \\
\hline Region (non-Pacific) & & & * & & * & & * & * & \\
\hline Population density & & & & $*$ & $*$ & $*$ & $*$ & $*$ & \\
\hline Percent Black & & & & $*$ & & & & $*$ & \\
\hline
\end{tabular}

Note: * statistically significant at 95 percent level of confidence based on the ordered logistic regressions.

progressive and tolerant than their parents (Owen and Dennis 1987; Tedin 1980); relative to older generations, Millenials express more socially egalitarian views and more liberal opinions when it comes to race, gender, gay rights, and abortion (Stoker and Bass 2011).

Ideally, to assess the extent to which biracials are "inheriting" liberal social positions, I would use the Freshman Survey data to compare the views of biracial respondents to those of their interracial parents. Unfortunately, the absence of parental political questions from the surveys preclude me from doing so. But as Jennings (2007) notes, when direct measures of parental political traits are lacking, family influence can be evaluated with parental socioeconomic traits. Parents' marital status can also matter for value inheritance; the intergenerational transmission of values deteriorates in divorced families because divorce weakens social connections between parents and children (Bengtson, Biblarz, and Roberts 2002). Examining the influence of parents' income, education, marital status, region, and neighborhood characteristics, then, allows me to capture the impact of status inheritance and shared social milieu on respondent political attitudes (Dalton 1982; Jennings, Stoker, and Bowers 2009).

Disentangling the Roles of Parentage and Experience. In order to shed some light on the political influence that interracial parents have on their biracial children, I assess the effects of parental covariates from the ordered logistic regressions. Statistically significant results are denoted in Table 6.23

Several noteworthy findings emerge from this analysis. First, religion is a significant predictor of political

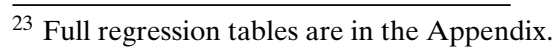

views across the board. Given that religious identification is passed down from parents to offspring (Myers 1996), this finding serves as evidence that parents are indirectly shaping their children's political attitudes via the transmission of religious faith.

Beyond the effects of religion, other parental covariates are also influential-but primarily or solely on implicitly racial and nonracial matters. Notably, parents' marital status is predictive of biracials' opinions on four of these six issues; relative to comparable biracials whose parents are together, those whose parents are not currently together hold more liberal positions on criminals' rights, gun control, abortion, and same-sex marriage. Thus, all else equal, having a single parent is predictive of more liberal attitudes on most of the implicitly racial and nonracial issues. However, parents' marital status has no significant effect on explicitly racial issues, suggesting that opinions on these topics may be explained more by individual racial attachments and group identification than by parental attitude transmission. This implication is substantiated by the effects of several other factors-mother's race, neighborhood population density, and percent Blackthat are significant only on issues that are not explicitly racial. In addition, when it comes to the effect of parents' education, findings suggest that maternal influence exceeds paternal influence; whereas the impact of father's education is significant on only a single issue, mother's education significantly predicts opinion on five issues. ${ }^{24}$

\footnotetext{
${ }^{24}$ Not surprisingly, the influence of mother's education is most consistent on support for married women working outside the home, reflecting the positive effects of having a college-educated mother on childrens' beliefs about gender roles (specifically, women's rights to work and have careers).
} 
Qualitative evidence also suggests that the general passage of political outlook from parents to offspring shapes biracials' nonracial political outlooks. In particular, interview respondents took overall partisan cues from their parents. For example, one White-Blackidentifying woman who called herself "a strong liberal" noted that she followed the same campaigns as her parents, stating, "Mostly my political views are based on what my parents have taught me and what I have experienced." Another White-Black-identifying respondent similarly attributed her Democratic identification to "my family and living in such a liberal area" and posited that she would likely hold liberal beliefs even if she did not have a Black parent, because her (White) mother was liberal.

Consistent with the quantitative findings, one issue that is especially salient to biracials and indirectly tied to parental influences is same-sex marriage. Although race-based legal restrictions on marriage were outlawed decades ago, marriage equality is a topic that many biracial interviewees are especially sensitive to. As one White-Black-identifying woman put it, "I'm strongly for [same-sex marriage] because my parents wouldn't have been able to get married back in the day. Who is to say who can marry who?" Another Blackidentifying male said, "I can't argue about [same-sex marriage]. I consider it a human right."

Overall, quantitative and qualitative evidence imply that parental influences are more consequential for biracials' views on implicitly and nonracial issues than on racial ones. This is consistent with my hypothesis that racial attitudes in particular are tied more to social group identification. These findings are also bolstered by prior research showing that parental transmission of outlook is only part of the political socialization storyalso important are life cycle influences and other socializing agents (Jennings and Niemi 1968). As Bengtson $(1975,369)$ writes of adolescent attitudes, "Global orientations may be more reflective of the individual's unique personal biography, or of his or her response to sociohistorical events, than of effects attributable either to family or generational factors."

Indeed, when asked about racial policies, biracial interviewees frequently cited their personal experiences as explanations for their views. Support for explicitly racial issues was largely due to individual encounters with discrimination, which were perceived to be pervasive by several respondents. Biracials' mixed backgrounds and often ambiguous racial appearance leaves them susceptible to prejudice from multiple groups, which can make them acutely attuned to racial injustices. One Black-identifying male respondent felt that "biracial people face more racism from both ends of the spectrum," while another echoed that he had been discriminated against by both Blacks and Whites because of his background: "I wouldn't say it's day-to-day life that I feel discriminated on, but I definitely feel that people will look at skin color and features and make a determination about who I am and how they would associate me, and how they would classify me in a group of people. [...] I'm always aware that it's out there and it happens on a fairly regular basis."
Such attention to racial prejudice contributed to a perception of shared adversities and political commonality with Black Americans. Both White-Black and Black identifiers expressed these feelings, and also indicated that they felt the social privileges afforded to Whites did not extend to them. As one White-Blackidentifying woman put it, "I definitely feel a connection with the Black community as a whole, but not sure about the White community - it's not that I don't identify with the White community, it's that they haven't dealt with much hardships I guess." Another Blackidentifying male said that he would only feel political solidarity with Whites if "something negative were to happen, and there were to be a backlash" against Whites as a group. He also mentioned that as a mixedrace person, his support for "the advancement of minorities" extended beyond race to groups who were "underprivileged" and "fighting for more equality," including the poor.

\section{Relating Biracials' Experiences to Existing Racial} Identity Theory. Overall, the comments made by Biracial Blacks are consistent with W. E. B. Du Bois's (1903a) influential argument in The Souls of Black Folk. Du Bois argued that a central element of Black solidarity is a collective Black identity, rooted in a common historical and cultural background, though not necessarily a shared biological lineage. Biracials who identify as Black - and to a lesser degree, those who identify as White-Black-embody this conception of a collective Black political identity, as their racial attitudes reflect an allegiance, sense of personal awareness, and shared interest with Black Americans.

In contrast, such solidarity with Blacks is not evident among biracial White identifiers. For example, on the issue of affirmative action, one biracial White interviewee argued that while she believed in the value of racial and ethnic diversity, she also felt that "coming from an affluent middle class background and having a White parent," she had not faced many social or economic disadvantages that would make the policy particularly relevant for her.

To that end, these findings also extend Waters's (1999) theory of strategic ethnic distancing, which was originally developed as a model explaining immigrant incorporation in the United States. As Waters argues, ethnic distancing is an identification approach employed by some native Black West Indians to separate themselves from Black Americans, whom they consider inferior and low status. In order to appear distinct from Black Americans, Black West Indians will present themselves as immigrants (for example, by playing up their Caribbean accents). The results shown here indicate that some biracials similarly separate themselves from Black Americans by identifying as White-a label that contradicts traditional racial norms. In light of how Whiteness has been characterized in U.S. law and society, a White identification among biracials reflects a distancing from their Black background. And for both West Indian immigrants and Biracial Whites, subjective identification as non-Black American corresponds 
with a weak sense of political and social solidarity with Black Americans.

Although Biracial White-Black identifiers are also presenting themselves in a way that does not align with conventional racial categories, they are not engaging in strategic distancing from Black Americans, nor are they falling in between their monoracial groups. As qualitative evidence illustrates, identification for these individuals reflects a personal acknowledgment of mixed-race parentage as well as an emotional political connection to Black Americans that is grounded in a perceived shared historical experience of slavery, Jim Crow, and discrimination.

In this sense, the attitudinal patterns of Biracial White-Blacks, as well as Biracial Blacks, are like those of second-generation Black West Indians in the U.S., who see themselves as part of the Black American community (Waters 1999). The mechanisms of social and political attachments do differ between the groups. While second-generation West Indians incorporate a Black American identity primarily because they are ascribed this way by others ${ }^{25}$ Blackness is more escapable for biracials because their lighter skin tone and racially ambiguous phenotypes often make their race indeterminate to outsiders (Pauker, Weisbuch, Ambady, Sommers, Adams Jr., and Ivcevic 2009; Willadsen-Jensen and Ito 2006). Whereas biracials' Blackness can go undetected externally, it typically remains a key component of their internal political identity. Biracials who identify as White-Black and Black do so in part because they perceive an affective attachment to Blacks in light of the Black American community's struggles against racial oppressiona community to which biracials have always belonged (Davis 2001).

\section{DISCUSSION AND CONCLUSIONS}

"Census 2000 will go down in history as the event that began to redefine race in American society." - Kenneth Prewitt, former head of the U.S. Census Bureau ${ }^{26}$

The ability of Americans to self-identify with multiple racial groups has challenged longstanding assumptions about the meaning of race in the United States. Mixed-race individuals are no longer constrained to a single racial category, and their sociopolitical positions add nuance to our understanding of an entrenched racial divide.

High levels of White-Black identification illustrate a major shift in the shape of the U.S. color line, demonstrating that Americans of African heritage do not feel bound by the historical norm of hypodescent. This point is evidenced by Freshman Survey data showing that most biracials of White-Black parentage now opt to call themselves multiracial. It is further underscored by the fact that in the years since the Census race change, the White-Black-identifying population

\footnotetext{
${ }^{25}$ Notably, they are U.S.-born, lack an accent that highlights their ethnic heritage, and belong to Black American peer groups (Waters 1999).

${ }^{26}$ Quoted in Williams $(2006,2)$.
}

increased by 221 percent, to 2.5 million in 2014 (Bureau of the Census 2015).

But while the one-drop rule no longer strictly determines how biracials of White-Black parentage label themselves or are labeled by others, findings here show that the effects of this rule linger. Socially, Whiteness remains largely a non-option for biracials of WhiteBlack parentage, as illustrated by the very small percentage of Freshman Survey respondents who selfidentify as White. Research in social psychology (e.g., Ho, Sidanius, Levin, and Banaji 2011; Peery and Bodenhausen 2008) showing that White-Black biracials tend to be ascribed as non-White further suggests that "White" is unlikely to become a popular biracial label anytime soon. In addition, more often than not, White-Black identifiers express racial attitudes that are not much different from Blacks. This intimates that, at present, multiple-race identification does not necessarily correspond to substantially weaker attachments to the Black American community. Although racial group boundaries have become fuzzier and identification is no longer viewed as mutually exclusive, group political attitudes have not changed accordingly.

Still, the increasing number of multiple-race identifiers raises important questions about the future of Black American political solidarity. Prior literature has demonstrated that residential segregation strengthens individual ties to Black history and culture (Tate 1993), worshipping at Black churches shapes understanding of group interests (Calhoun-Brown 1996; HarrisLacewell 2006; Taylor 2002), and the "shared experience of deprivation" is a fundamental facet of Black group consciousness (Gay 2004). But this article has shown that, relative to Monoracial Blacks, biracials are more likely to live in racially diverse neighborhoods, are much less religious, and come from higher SES households. If these demographic and identification patterns persist and Black intermarriage rates continue to rise in the coming years, ${ }^{27}$ the racial attitudes of White-Black identifiers may well diverge from those of Black identifiers down the road. This would intimate a more racially stratified society wherein racial identification, skin tone, social class, and political ideology are tightly linked. Thus the ability to identify with multiple races may ultimately stigmatize lower SES, darkerskinned, monoracial minorities by enabling people of mixed-race to distinguish themselves from these groups. But only time will tell whether this turns out to be the case.

More generally, the findings here demonstrate that by implicitly presuming that all respondents who identify with a particular racial group (e.g., "Black") view the world through a single racial lens, researchers inadvertently mask the political influence of racial parentage. To the extent that we associate race with certain political meanings, and we structure our models of public opinion and racial attitudes around these meanings, such findings are noteworthy. Although the races with which biracials label themselves say much about their political solidarity, these labels sometimes conceal

\footnotetext{
27 The rate of intermarriage among Black newlyweds increased from 15.5 percent in 2008 to 17.1 percent in 2010 (Wang 2012).
} 
race's impact on attitudes. For example, Biracial Whites are significantly more likely than Monoracial Whites to value racial tolerance and support affirmative actionindicating that while Biracial Whites present themselves as being part of the racial majority, their racial outlook is indicative of their minority background. For White-identified biracials, the decision to label with their majority race is not a "denial" or rejection of their Black heritage, but rather a reflection that race is a mostly inconsequential factor in their day-to-day lives.

This research has integrated and extended previously unconnected theories across political science, sociology, and social psychology, and findings also contribute to broader literatures on the political consequences of racial and ethnic identification (Chandra 2006; Dawson 1994). The results here inform our understanding of how self-identification corresponds with social group connections. Research on political attachments has consistently found that subjective group allegiances are more influential than objective group membership (Huddy 2003; Waters 1990). Indeed, these findings show that not all biracials of White-Black parentage feel a strong sense of attachment to each of their component racial heritages. There are clear attitudinal differences among biracials that correspond with their chosen racial labels. At the same time, self-identification alone does not explain social attitudes; biracials are also influenced by their mixed-race background - even if they do not self-identify with multiple races.

Some limitations to the Freshman Surveys should be noted. First, these data do not allow for an examination of the influence of racial discrimination or physical appearance on opinion; it is plausible that biracials who are darker-skinned are more likely to support anti-discrimination legislation or other racial policies than biracials with lighter skin. However, my qualitative evidence suggests that skin tone and appearance play a relatively minor role in the construction of attitudes, which is consistent with prior research findings (Hochschild and Weaver 2007). ${ }^{28}$

In addition, these data represent biracials' selfidentification and political attitudes in early adulthood, as reported on a survey. This measure is meaningful because it reflects individuals' internal understanding of race and politics, but it does not enable me to speak to the durability of attitudes and identification across time and circumstance. Given their age, and that this is, for many, their first experience away from home, it would also be worthwhile to examine whether and to what extent biracials' self-identification and attitudes evolve over college.

This work has centered on the political consequences of racial identification for White-Black biracial Americans, due to the size of this group, the high levels of social distance between Whites and Blacks, and the traditionally strict definition of what constitutes "Black"

\footnotetext{
${ }^{28}$ Many interviewees said that their racial views were based less on physical resemblance and more on emotional attachments to a particular racial group. For example, despite feeling that he was "pretty White in color," one biracial male identified as Black because of his close relationship with his Black relatives.
}

in American society. Yet it would be remiss to overlook other biracial subgroups, especially given the racial and ethnic disparities in intermarriage and the millions of multiple-race identifiers who do not label themselves as White-Black. ${ }^{29}$ For biracials of Hispanic or Asian descent, national origin, foreign language fluency, and proximity to the immigrant experience all likely shape both identification choice and political outlook. But the general findings discussed here may have implications for these other subgroups. It is plausible that, in light of their experiences as racial minorities, the perception that racism is an important social problem is a widely held belief among multiple-race identifiers in general. Future projects must examine these other racial groups. Such research should also assess whether biracials have especially liberal attitudes towards economic issues, such as support for downwardly redistributive policies, and whether they express greater relative support for policies affecting socially marginalized groups such as the sick or disabled.

All told, these findings underscore that identification is more than a subjective expression of racial group belonging, or the "accurate" labeling of oneself with both constituent parental races. The social encounters associated with having multiple racial backgrounds also shape perceptions about racial policies and egalitarianism. Perhaps it should not be so surprising, then, that the attitudes of White-Black biracials are sometimes disparate from conventional monoracial groups, falling outside of the monoracial White and Black spectrum. Contrary to the conventional wisdom, on nonracial policy issues, Americans of White-Black parentage who opt to label themselves as racial minorities constitute not an intermediate group positioned between two more deeply rooted races, but a distinct group unto themselves.

\section{SUPPLEMENTARY MATERIAL}

To view supplementary material for this article, please visit http://dx.doi.org/10.1017/S0003055415000556

\section{REFERENCES}

Bailey, Stanley R. 2008. "Unmixing for Race Making in Brazil." American Journal of Sociology 114 (3): 577-614.

Banks, Ralph Richard. 2011. Is Marriage for White People?: How the African American Marriage Decline Affects Everyone. New York: Dutton Adult.

Beck, Paul Allen, and M. Kent Jennings. 1991. "Family Traditions, Political Periods, and the Development of Partisan Orientations." The Journal of Politics 53 (03): 742-63.

Bengtson, Vern L. 1975. "Generation and Family Effects in Value Socialization." American Sociological Review 40 (3): 358-71.

Bengtson, Vern L., Timothy J. Biblarz, and Robert E. L. Roberts. 2002. How Families Still Matter: A Longitudinal Study of Youth in Two Generations. New York: Cambridge University Press.

\footnotetext{
${ }^{29}$ Among those who married in 2010, 28 percent of Asians and 26 percent of Hispanics married outside of their group, compared to 17 percent of Blacks and 9 percent of Whites (Wang 2012). Of the 9.4 million multiple-race identifiers in 2013, 25 percent identified as White-Black, while the remainder identified with some other combination of races (most common were White-American Indian, White-Asian, or White-Some Other Race) (Bureau of the Census 2013).
} 
Bowles, Dorcas D. 1993. "Bi-racial Identity: Children Born to African-American and White Couples." Clinical Social Work Journal 21 (4): 417-28.

Bracey, Jeana R., Mayra Y. Bamaca, and Adriana J. Umana-Taylor. 2004. "Examining Ethnic Identity and Self-Esteem Among Biracial and Monoracial Adolescents." Journal of Youth and Adolescence 33 (2): 123-32.

Bratter, Jenifer. 2007. "Will "Multiracial Survive to the Next Generation?: The Racial Classification of Children of Multiracial Parents." Social Forces 86 (2): 821-49.

Bratter, Jenifer L., and Rosalind B. King. 2008. "But Will It Last?: Marital Instability Among Interracial and Same-Race Couples.' Family Relations 57 (2): 160-71.

Brunsma, David L. 2005. "Interracial Families and the Racial Identification of Mixed-Race Children: Evidence from the Early Childhood Longitudinal Study." Social Forces 84 (2): 1131-57.

Brunsma, David L. 2006. "Public Categories, Private Identities: Exploring Regional Differences in the Biracial Experience." Social Science Research 35 (3): 555-76.

Bureau, of the Census, American FactFinder. 2015. "Detailed Race: 2014 American Community Survey 1-Year Estimates." Census Summary File 1(SF1) 100-Percent Data.

Calhoun-Brown, Allison. 1996. "The Politics of African American Churches." Journal of Politics 58: 535-93.

Campbell, Mary E. 2007. "Thinking Outside the (Black) Box: Measuring Black and Multiracial Identification on Surveys." Social Science Research 36 (3): 921-44.

Chandra, Kanchan. 2006. "What is Ethnic Identity and Does it Matter?" Annual Review of Political Science 9: 397-424.

Cheng, Simon, and Kathryn J. Lively. 2009. "Multiracial SelfIdentification and Adolescent Outcomes: A Social Psychological Approach to the Marginal Man Theory." Social Forces 88 (1): 61 98.

Connell, R. W. 1972. "Political Socialization in the American Family: The Evidence Re-Examined." Public Opinion Quarterly 36 (3) 323-33.

Conover, Pamela Johnston. 1984. "The Influence of Group Identifications on Political Perception and Evaluation." The Journal of Politics 46 (3): 760-85.

DaCosta, Kimberly McClain. 2007. Making Multiracials: State, Family, and Market in the Redrawing of the Color Line. Stanford, CA: Stanford University Press.

Dalmage, Heather M. 2000. Tripping on the Color Line: Black-White Multiracial Families in a Racially Divided World. New Brunswick, NJ: Rutgers University Press.

Dalton, Russell J. 1982. "The Pathways of Parental Socialization." American Politics Research 10 (2): 139-57.

Davenport, Lauren D. 2016. "The Role of Gender, Class and Religion in Biracial Americans Racial Labeling Decisions." American Sociological Review 81 (1).

Davis, F. James. 2001. Who is Black?: One Nation's Definition. University Park, PA: Pennsylvania State University Press.

Dawson, Michael C. 1994. Behind the Mule: Race and Class in African-American Politics. Princeton, NJ: Princeton University Press.

Dawson, Michael C. 2001. Black Visions: The Roots of Contemporary African-American Political Ideologies. Chicago: University of Chicago Press

Du Bois, W. E. B. 1903a. The Souls of Black Folk (1989edition ). New York: Bantam.

Du Bois, W. E. B. 1903b. The Talented Tenth. New York: James Pott and Company.

Eskridge Jr, William N. 1993. "A History of Same-Sex Marriage." Virginia Law Review 79: 1419-513.

Farley, Reynolds. 2002. "Racial Identities in 2000: The Response to the Multiple-Race Response Option." In The New Race Question: How the Census Counts Multiracial Individuals, eds. Joel Perlmann and Mary C. Waters. New York: Russell Sage, 33-61.

Flagg, Barbara J. 1993. "Was Blind, But Now I See: White Race Consciousness and the Requirement of Discriminatory Intent." Michigan Law Review 91 (5): 953-1017.

Fryer, Roland G. 2007. "Guess Who's Been Coming to Dinner? Trends in Interracial Marriage Over the 20th Century." The Journal of Economic Perspectives 21 (2): 71-90.
Fryer Jr, Roland G., Lisa Kahn, Steven D. Levitt, and Jorg L. Spenkuch. 2012. "The Plight of Mixed Race Adolescents." The Review of Economics and Statistics, MIT Press 94 (3).

Gay, Claudine. 2004. "Putting Race in Context: Identifying the Environmental Determinants of Black Racial Attitudes." American Political Science Review 98 (4): 547-62.

Gilens, Martin. 1999. Why Americans Hate Welfare: Race, Media, and the Politics of Antipoverty Policy. Chicago: University of Chicago Press.

Greenstein, Fred I. 1965. Children and Politics. New Haven, CT: Yale University Press.

Gullickson, Aaron, and Ann Morning. 2011. "Choosing Race: Multiracial Ancestry and Identification." Social Science Research 40 (2): 498-512

Haider-Markel, Donald P., and Mark R. Joslyn. 2005. "Attributions and the Regulation of Marriage: Considering the Parallels Between Race and Homosexuality." PS: Political Science and Politics 38 (2): 233-9.

Haney-Lopez, Ian. 2006. White By Law: The Legal Construction of Race. New York: NYU Press.

Harris, David R., and Jeremiah Joseph Sim. 2002. "Who is Multiracial? Assessing the Complexity of Lived Race." American Sociological Review 67 (4): 614-27.

Harris-Lacewell, Melissa V. 2006. Barbershops, Bibles, and BET: Everyday Talk and Black Political Thought. Princeton, NJ: Princeton University Press.

Hess, Robert D., and Judith Torney. 1967. The Development of Political Attitudes in Children. Chicago: Aldine De Gruyter.

Ho, Arnold K., Jim Sidanius, Daniel T. Levin, and Mahzarin R. Banaji. 2011. "Evidence for Hypodescent and Racial Hierarchy in the Categorization and Perception of Biracial Individuals." Journal of Personality and Social Psychology 100 (3): 492.

Hochschild, Jennifer L., and Vesla Weaver. 2007. "The Skin Color Paradox and the American Racial Order." Social Forces 86 (2): 643-70.

Hochschild, Jennifer L., and Vesla Weaver. 2010. “There's No One as Irish as Barack O'Bama': The Politics and Policy of Multiracialism in the United States." Perspectives on Politics 8 (3): 737-60.

Hochschild, Jennifer L., Vesla M. Weaver, and Traci R. Burch. 2012. Creating a New Racial Order: How Immigration, Multiracialism, Genomics, and the Young Can Remake Race in America. Princeton: Princeton University Press.

Huddy, Leonie. 2003. "Group Identity and Political Cohesion. " In Oxford Handbook of Political Psychology, eds. Leonie Huddy, David O. Sears, and Robert Jervis. New York: Oxford University Press, 511-58.

Humes, Karen R., Nicholas A. Jones, and Roberto R. Ramirez. 2011. "Overview of Race and Hispanic Origin: 2010." 2010 Census Briefs, 1-23.

Hutchings, Vincent L., and Nicholas A. Valentino. 2004. "The Centrality of Race in American Politics." Annual Review of Political Science 7: 383-408.

Hyman, Herbert 1959. Political Socialization. New York: Free Press. Jaret, Charles, and Donald C. Reitzes. 1999. "The Importance of Racial-Ethnic Identity and Social Setting for Blacks, Whites, and Multiracials." Sociological Perspectives 42 (4): 711-37.

Jennings, M. Kent. 2007. "Political Socialization." In The Oxford Handbook of Political Behavior, eds. Russell J. Dalton and HansDieter Klingemann. Oxford: Oxford University Press, 29-44.

Jennings, M. Kent, and Richard G. Niemi. 1968. "The Transmission of Political Values from Parent to Child." The American Political Science Review 62 (1): 169-84.

Jennings, M. Kent, Laura Stoker, and Jake Bowers. 2009. "Politics Across Generations: Family Transmission Reexamined." Journal of Politics 71 (3): 782-99.

Kanaiaupuni, Shawn M., and Carolyn A. Liebler. 2005. "Pondering Poi Dog: Place and Racial Identification of Multiracial Native Hawaiians." Ethnic and Racial Studies 28 (4): 687-721.

Keith, Verna M., and Cedric Herring. 1991. "Skin Tone and Stratification in the Black Community." American Journal of Sociology 97 (3): 760-78.

Kerwin, Christine, Joseph G. Ponterotto, Barbara L. Jackson, and Abigail Harris. 1993. "Racial Identity in Biracial Children: A Qualitative Investigation." Journal of Counseling Psychology 40 (2): 221-31. 
Khanna, Nikki. 2011. Biracial in America: Forming and Performing Racial Identity. Lanham, MD: Lexington Books.

Kinder, Donald R., and Lynn M. Sanders. 1996. Divided By Color: Racial Politics and Democratic Ideals. Chicago: University of Chicago Press.

Kosmin, Barry A., and Ariela Keysar. 2009. "American Religious Identification Survey Summary Report." Hartford, CT: Institute for the Study of Secularism in Society and Culture, Trinity College.

Lee, Taeku. 2008. "Race, Immigration, and The Identity-to-Politics Link." Annual Review of Political Science 11: 457-78.

Luker, Kristin. 1984. Abortion and the Politics of Motherhood. Berkeley, CA: University of California Press.

Masuoka, Natalie. 2008. "Political Attitudes and Ideologies of Multiracial Americans: The Implications of Mixed Race in the United States." Political Research Quarterly 61 (2): 253-67.

Masuoka, Natalie. 2011. "The 'Multiracial' Option: Social Group Identity and Changing Patterns of Racial Categorization." American Politics Research 39 (1): 176-204.

McLeod, Jane D., and Ronald C. Kessler. 1990. "Socioeconomic Status Differences in Vulnerability to Undesirable Life Events." Journal of Health and Social Behavior 31 (2): 162-72.

Myers, Scott M. 1996. "An Interactive Model of Religiosity Inheritance: The Importance of Family Context." American Sociological Review 61 (5): 858-66.

Myrdal, Gunnar. 1944. An American Dilemma: The Negro Problem and Modern Democracy. New York: Harper \& Row.

Nagel, Joane. 1995. "American Indian Ethnic Renewal: Politics and the Resurgence of Identity." American Sociological Review 60 (6): 947-65.

National Center for Education Statistics, Institute of Education Sciences. 2014. "Fast Facts: Back to School Statistics." U.S. Department of Education. http://nces.ed.gov/fastfacts/display.asp?id=372

Niemi, Richard G., and M. Kent Jennings. 1991. "Issues and Inheritance in the Formation of Party Identification." American Journal of Political Science 35 (4): 970-88.

Nobles, Melissa. 2000. Shades of Citizenship: Race and the Census in Modern Politics. Stanford, CA: Stanford University Press.

Norris, Floyd. 2014. "Fewer U.S. Graduates Opt for College After High School." The New York Times, April 25, p. B3. http://www. nytimes.com/2014/04/26/business/fewer-us-high-school-graduatesopt-for-college.html

Owen, Diana, and Jack Dennis. 1987. "Preadult Development of Political Tolerance." Political Psychology 8 (4): 547-61.

Park, Robert E. 1928. "Human Migration and the Marginal Man." American Journal of Sociology 33 (6): 881-93.

Park, Robert E. 1931. "Mentality of Racial Hybrids." American Journal of Sociology 36 (4): 534-51.

Pauker, Kristin, Max Weisbuch, Nalini Ambady, Samuel R. Sommers, Reginald B. Adams Jr, and Zorana Ivcevic. 2009. "Not So Black and White: Memory for Ambiguous Group Members." Journal of Personality and Social Psychology 96 (4): 795.

Peery, Destiny, and Galen V. Bodenhausen. 2008. "Black + White = Black: Hypodescent in Reflexive Categorization of Racially Ambiguous Faces." Psychological Science 19 (10): 973-7.

Pew. 2015. "Multiracial in America: Proud, Diverse and Growing in Numbers." Pew Research Center Social \& Demographic Trends. Washington, D.C.: Pew Research Center.

Pew Research Center. 2013. "A Portrait of Jewish Americans." Pew Religion and Life Project. Washington, D.C.: Pew Research Center.

Qian, Zhenchao. 2004. "Options: Racial/Ethnic Identification of Children of Intermarried Couples." Social Science Quarterly 85 (3): 746-66.

Reuter, Edward Byron. 1918. The Mulatto in the United States. Boston: Gorham Press.

Rockquemore, Kerry, and David L. Brunsma. 2008. Beyond Black: Biracial Identity in America, 2nd. edition. Lanham, MD: Rowman \& Littlefield Publishers Inc.

Root, Maria P. P. 2001. Love's Revolution: Interracial Marriage. Philadelphia: Temple University Press.

Rosenfeld, Michael J. 2007. The Age of Independence: Interracial Unions, Same-Sex Unions, and the Changing American Family. Cambridge, MA: Harvard University Press.
Roth, Wendy D. 2005. "The End of the One-Drop Rule? Labeling of Multiracial Children in Black Intermarriages." Sociological Forum 20 (1): 35-67.

Sax, Linda, Alexander W. Astin, Jennifer A. Lindholm, William S. Korn, Victor B. Saenz, and Kathryn M. Mahoney. 2003. The American Freshmen: National Norms for Fall 2003. Los Angeles, CA: Higher Education Research Institute, UCLA.

Sax, Linda, Jennifer A. Lindholm, Alexander W. Astin, William S. Korn, and Kathryn M. Mahoney. 2001. The American Freshmen: National Norms for Fall 2001. Los Angeles, CA: Higher Education Research Institute, UCLA.

Sax, Linda, Jennifer A. Lindholm, Alexander W. Astin, William S. Korn, and Kathryn M. Mahoney. 2002. The American Freshmen: National Norms for Fall 2002. Los Angeles, CA: Higher Education Research Institute, UCLA.

Shelby, Tommie. 2005. We Who are Dark: The Philosophical Foundations of Black Solidarity. Cambridge, MA: Harvard Belknap Press.

Spencer, Rainier. 2004. "Assessing Multiracial Identity Theory and Politics: The Challenge of Hypodescent." Ethnicities 4 (3): 357-79.

Spickard, Paul R., and W. Jeffrey Burroughs. 2000. We Are a People: Narrative and Multiplicity in Constructing Ethnic Identity. Philadelphia: Temple University Press.

Stoker, Laura, and Jackie Bass. 2011. "Political Socialization: Ongoing Questions and New Directions." In The Oxford Handbook of American Public Opinion and the Media, eds. Robert Y. Shapiro and Lawrence R. Jacobs. New York: Oxford University Press.

Stonequist, Everett V. 1935. "The Problem of the Marginal Man." American Journal of Sociology 41 (1): 1-12.

Tajfel, Henri. 1981. Human Groups and Social Categories: Studies in Social Psychology. New York: Cambridge University Press.

Tajfel, Henri, and John C. Turner. 1986. The Social Identity Theory of Integroup Behaviour. In Psychology of Intergroup Relations, eds. S. Worchell, and W. G. Austin. Chicago: Nelson-Hall, 7-24.

Tate, Katherine. 1993. From Protest to Politics. New York: Russell Sage Foundation.

Taylor, Clarence. 2002. Black Religious Intellectuals. New York: Routledge.

Tedin, Kent L. 1980. "Assessing Peer and Parent Influence on Adolescent Political Attitudes." American Journal of Political Science 24 (1): 136-54

Telles, Edward E., and Christina A. Sue. 2009. "Race Mixture: Boundary Crossing in Comparative Perspective." Annual Review of Sociology 35: 129-46.

Thomas, L. Eugene. 1971. "Political Attitude Congruence Between Politically Active Parents and College-Age Children: An Inquiry Into Family Political Socialization." Journal of Marriage and the Family 33 (2): 375-86.

Troll, Lillian E., Bernice L. Neugarten, and Ruth J. Kraines. 1969. "Similarities in Values and Other Personality Characteristics in College Students and Their Parents." Merrill-Palmer Quarterly of Behavior and Development 15 (4): 323-36.

Wang, Wendy. 2012. "The Rise of Intermarriage: Rates, CharacteristicsVary by Race and Gender." Washington, D.C.: Pew Research Center.

Waters, Mary C. 1990. Ethnic Options: Choosing Identities in America. Berkeley, CA: University of California Press.

Waters, Mary C. 1999. Black Identities: West Indian Immigrant Dreams and American Realities. Cambridge, MA: Harvard University Press.

White, Walter. 1948. A Man Called White: The Autobiography of Walter White. New York: Viking.

Williams, Kim M. 2006. Mark One or More: Civil Rights in Multiracial America. Ann Arbor: University of Michigan Press.

Willadsen-Jensen, Eve C., and Tiffany A. Ito. 2006. "Ambiguity and the Timecourse of Racial Perception." Social Cognition 24 (5): 580-606.

Xie, Yu, and Kimberly Goyette. 1997. "The Racial Identification of Biracial Children With One Asian Parent: Evidence From the 1990 Census." Social Forces 76 (2): 547-70.

Zhang, Yuanting, and Jennifer Van Hook. 2009. "Marital Dissolution Among Interracial Couples." Journal of Marriage and Family 71 (1): $95-107$ 